\title{
Does International Financial Integration Spur Economic Growth? Evidence from Pakistan
}

\author{
Shaikh Muhammad Saleem *
}

\begin{abstract}
The degree of international financial integration has seen a drastic change recently, especially during the last two decades. This study attempts to explore the relationship between international financial integration and economic growth in the context of Pakistan through a sample of data from 1975 to 2013 using time series analysis. International financial integration is used as an index that comprises foreign direct investment, remittances, and external debts. The results indicate that international financial integration has a significant and negative effect on economic growth. Cointegration results have found a significant and long run relationship, whereas variance decomposition method shows bidirectional causal relationship. The sensitivity analysis proves that the initial result is robust through fully modified ordinary least square method, while Cusum and Cusum of square proves stability of coefficients over a long period.
\end{abstract}

Keywords: Time Series Model, International Financial Integration, Economic Growth.

\section{Introduction}

An efficient and stable financial system is essential in a modern economy to assist economic transactions, specialization in production, provision of investor-friendly business environment, competitive domestic markets, mobilization of savings, and exchange of goods and services (Alam, Raza, Shahbaz, \& Abbas, 2016; Raza \& Karim, 2016; Sharif \& Raza, 2016). A stable financial system not only reduces uncertainty and cost of transactions, but also improves the overall economic efficiency through the efficient allocation of resources, diversifying risk, and transfer of technology (Khan, Qayyum, Sheikh, \& Siddique, 2005; Khan, 2007). The past extensive literature mainly discusses financial globalization, financial development, and financial market imperfections in relation to economic growth in the panel and cross-sectional data. Among these factors, the role of international financial integration (IFI) in growth enhancement has recently received considerable attention especially in the developing economies. We developed a model of international financial integration and economic growth relationship by using long time series data. On this path, Prasad, Rogoff, Wei, and Kose (2003) argued that IFI may open the door for additional capital, but it is unlikely to offer a major boost to economic growth itself. If domestic governance is sufficiently weak, financial integration could cause a flight of domestic capital and may also lower the growth rate. Similarly, IFI may enhance the performance of domestic financial

\footnotetext{
*Lecturer, Pakistan Shipowners' College, Karachi, Pakistan.

E-mail:sheikhsaleem.m@gmail.com
} 
systems through strengthening competition and financial services, with positive growth effects (Levine, 2001). IFI is likely to encourage the efficiency of the financial intermediaries and less financially developed markets. This improved efficiency motivates demand for funds and financial services due to the increased size of domestic financial markets (Guiso, Jappelli, Padula, \& Pagano, 2004). This leads us to the question: whether international financial integration affect economic growth in Pakistan during the last four decades? We attempt to answer this question with the aim to shed new light on the topic and create an IFI index.

In our view, rising global linkages, especially financial linkages, constitute one of the most important economic phenomena over the last two or three decades in terms of understanding how IFI and long-run growth are related. Existing literature on IFI and economic growth is not well researched in the context of Pakistan, and this addition provides a point of departure for this paper. The next section contains channel discussion and empirical literature on IFI and economic growth using time series, panel, and cross-sectional data. Section 3 represents a linear model with control variables through econometric techniques, while section 4 contains the results of data analysis and estimations, followed by the conclusion and policy suggestions in section 5 .

\section{Figure 1}

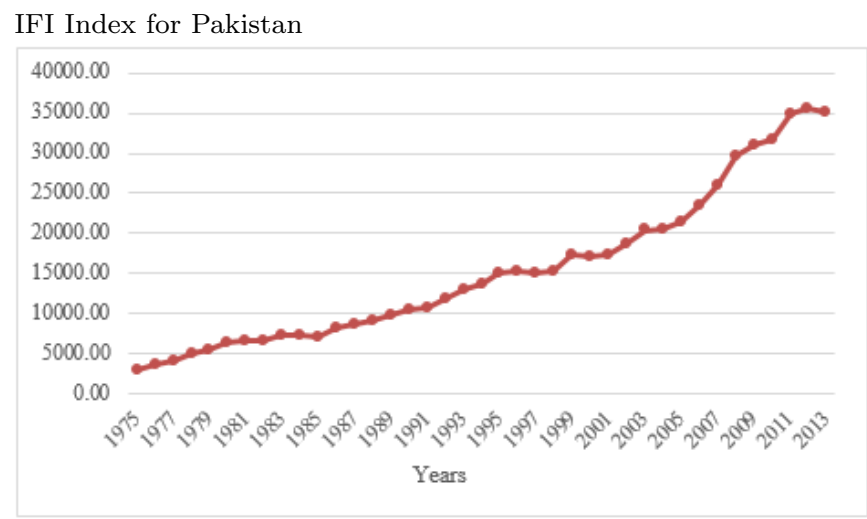

Source: Author's estimation

IFI index comprises foreign direct investment, remittances, and external debts for the year 1975 to 2013. Figure 1 shows an increasing trend of IFI during the last four decades in Pakistan and external debt takes a large share in this index.

\section{Principal Component Analysis}

Principal Component Analysis (PCA) was conceived by Pearson (1901) and then developed by Hotelling (1933). Most of the researchers Kolenikov and Angeles (2009); Filmer and Pritchett (2001); Hye and Lau (2015) used PCA for the construction of index because it is a multivariate technique to ensure the relationship between quantitative variables. 
This technique extracts common measures from a set of linear combination of variables that capture the frequent information most effectively. PCA overcomes indeterminacy by finding the linear combination of the variables with maximum variance (Filmer \& Pritchett, 2001).

\section{Construction of IFI index}

Researchers may use IFI as either a built-in index or a single proxy, but we constructed composite IFI index to check the effect of foreign direct investment (FDI), Remittances (REM), and External debt (EXD). Although different proxies and indices are available in the empirical studies, generally FDI, Remittances, and External debt are used as a proxy of IFI, but they have not been used together as a single model in Pakistan. In this case, if any one variable is selected among them, it may not represent the true picture of IFI. Therefore, this study used three different proxies together (FDI, REM, EXD) and constructed an IFI index by Principle Component Analysis (PCA) with time series data from 1975 to 2013. PCA (eigenvalues) in table 1 explains $77.3 \%, 16.8 \%$, and $5.9 \%$ proportion respectively, thus we took the first PC to calculate IFI index. Next values of loading-vector in PC 1 were used because it explains higher variation as compared to the rest of the combinations in PCs.

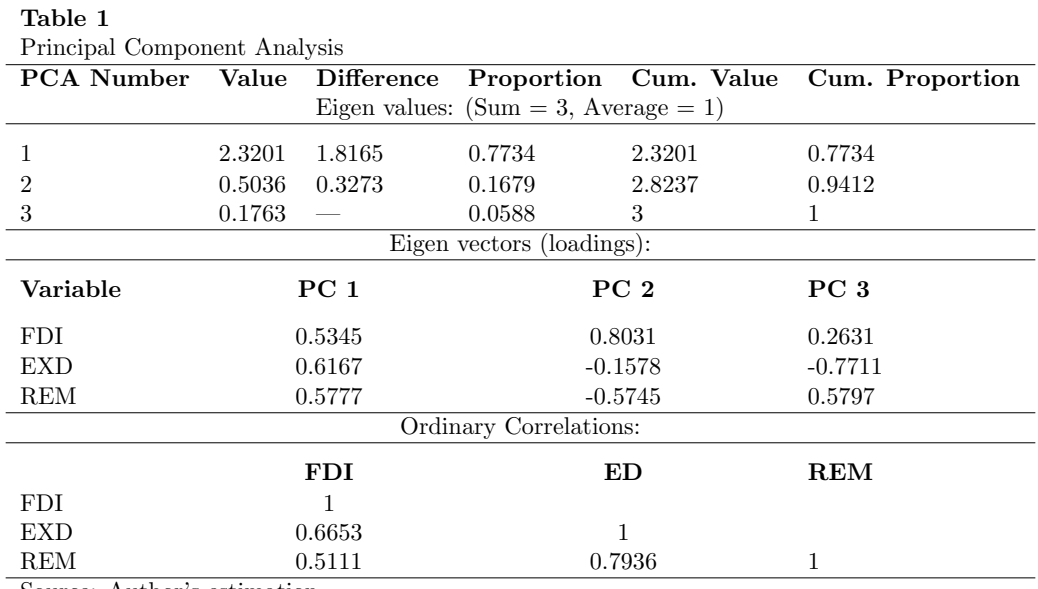

\section{Theoretical Channel}

A number of theories have given channels about financial globalization, but IFI and growth channels remain a challenge. As financial globalization comes under the broad way term that refers to the expansion of global financial flows, hence financial integration connects an individual country's linkages with the world market (Prasad et al., 2003). Similarly, financial globalization or globalization of financial markets is considered integration of a 
local financial system with international financial markets and institutions (World Bank, Global Development Finance, 2010).

\section{IFI and Growth Nexus}

Theoretically, it is difficult to prove IFI and growth relationship either negative or positive effects, but generally, researchers Masten, Coricelli, and Masten (2008); Kose, Prasad, and Terrones (2006); Epaulard and Pommeret (2005); Prasad et al. (2003); De Gregorio (1999) have linked IFI with economic growth in two possible dimensions. In the same way, we discuss direct channel and indirect channel respectively in the following sections.

Baele, Ferrando, Hördahl, Krylova, and Monnet (2004) examined the effect of financial integration on economic growth through larger financial development. Financial development and financial integration are more important because they are linked with growth (Tayebi \& Fakhr, 2009). According to the direct effect, the strong financial system generally reduces uncertainty through facilitating trade, hedging, and risk diversification Masten et al. (2008); Epaulard and Pommeret (2005); Prasad et al. (2003); Baele et al. (2004), and increases risk-sharing opportunity among domestic and foreign investors. Firms may also increase their ability to diversify risk and encourage more investment to increase productivity that leads to growth. Secondly, capital resources Masten et al. (2008); Epaulard and Pommeret (2005); Baele et al. (2004); Prasad et al. (2003) improve through capital inflows that increase the liquidity of domestic stock and further reduce equity risk. Thus, lowering the cost of capital encourages investment. In addition, increased foreign ownership generates a variety of benefits (Prasad et al., 2003). Thirdly, mobilized savings become an investment Mougani (2012); Epaulard and Pommeret (2005); Prasad et al. (2003), therefore, the efficiency of investment includes total factor productivity and standard measures of investment. Similarly, financial intermediation contributes to raising savings rate, which becomes investment rate. Fourthly, through the transfer of technology Epaulard and Pommeret (2005); Prasad et al. (2003), foreign firms introduce new instruments and techniques and these changes foster technological shift in the domestic market. Technical advancement enhances production accumulation and accelerates economic growth.

On the other side, the development of the domestic financial market and improvement in institutional framework may affect indirectly on economic growth (Masten et al., 2008; Prasad et al., 2003). Firstly, foreign firms increase the degree of competition and put pressure on local firms to reduce cost and minimize profits. Later this pressure stabilizes profit of local firms and encourages domestic investment, which leads to economic growth (Markusen \& Venables, 1999). This also stimulates demand for funds and enhances domestic financial market. Secondly, financial integration affects domestic financial market through improvement in the institutional framework. The improvement in policies, regulation, and governance enhances overall stability reducing the problems of asymmetric information (Masten et al., 2008).

The channels discussed above illustrate many possible effects of IFI on the economic growth, but there are emerging ways which are still theoretically ambiguous. Therefore, we review past empirical studies for further explanation in the next section. 


\section{Empirical Analysis}

This section highlights the recent studies related to IFI and economic growth.

De Gregorio (1999) analyzed the relationship between international financial integration and economic growth over the period of 1960 to 1993 with 24 economies. The results proved the positive relationship between international financial integration and domestic financial system, and no direct effect of financial integration on economic growth was found without controlling the domestic capital market. It was concluded that the beneficial effect of financial integration on economic growth can be achieved by fostering the development of domestic financial system.

Alfaro, Chanda, Kalemli-Ozcan, and Sayek (2004) examined the links among foreign direct investment, financial market, and economic growth using data from 39 countries covering the period of 1981 to 1997. The results confirmed a causal relationship as well as a positive and significant effect of FDI on growth. It was also proved that FDI promotes economic growth through financial markets.

Edison, Levine, Ricci, and Sløk (2002) assessed the relationship between international financial integration and economic growth with other potential determinants that are economic development, financial development, legal system development, government corruption, and macroeconomic policies. The paper used panel estimates by taking data from 57 countries from 1980 to 2000 . It was found that financial integration itself does not enhance growth, even if potential determinants are controlled.

Kose, Prasad, and Terrones (2003) examined the impact of international financial integration on economic growth volatility over the period of 1960 to 1999 . According to the results, volatility of consumption growth relative to income growth has increased for more financially integrated developing countries in the 1990s. On the other side, financial openness is associated with rising consumption, but only at the specified level. It was concluded that developing economies need more integration to the world financial market to get benefits from financial integration by improving risk sharing.

Christopoulos and Tsionas (2004) investigated the long-run relationship between financial development and economic growth by using combined cross-sectional and time series data from 10 developing countries from 1970 to 2000. Panel cointegration found strong evidence in favor of the hypothesis that long run causality exists between financial development and growth, and their relationship is significant

Epaulard and Pommeret (2005) evaluated welfare gains from financial integration with economic growth and volatility by studying 32 economies. The group of economies was divided into more integrated economies (MIEs) and less integrated economies (LIEs), and data were collected from the period of 1990 to 1998. It was concluded that gains from financial integration are not huge, but they are significant as financial integration brings about 0.3 percent yearly growth.

Kose et al. (2006) investigated trade and financial integration with growth and volatility by taking data from 23 more financially integrated economies (MFI) and 41 less financially integrated economies from the period of 1960 to 2000. It is argued that trade and financial integration appear to weaken negative growth-volatility relationship. Schularick and Steger (2006) examined whether financial integration boosts economic growth in 24 developing and 
developed countries by taking data from 1980 to 2002. It was revealed that international financial integration could contribute to higher economic growth by protecting property rights for the standard neoclassical model, but it would fail to do so today.

Masten et al. (2008) analyzed potential effects of financial integration on economic growth and national financial markets with financial development in Europe ${ }^{1}$ by taking panel data from 1996 to 2004. The results found that financial integration does not have a positive effect on growth itself because it also depends on the level of financial development, macroeconomic stability, and institutional quality. However, this effect is positive in those EU countries where sufficient absorptive capacity is measured. On the contrary, the development of financial market has a positive effect on growth.

Kose, Prasad, and Taylor (2011) investigated threshold level of financial integration for the attainment of economic growth. He proposed that indirect benefits of financial integration might be more effective than traditional financing after reducing the risk of financial openness. The results found that FDI and portfolio flows are safer than debt flow because a definite threshold cannot be claimed.

Mougani (2012) examined the impact of international financial integration on economic growth in the context of closed and open African countries using cross-sectional and panel data from 1976 to 2009. It was found that international financial integration does not accelerate economic growth, even under particular economic and financial conditions.

Farid (2013) investigated financial integration and economic growth in Africa during the period of 1980 to 2010 using panel data. It was found that those African economies, which are more open to international capital flows, have not grown faster than the rest. Financial integration was also identified as a potential cause of instability.

Law and Singh (2014) analyzed the impact of finance on economic growth using panel data from 87 developed and developing countries from 1980 to 2010. The results concluded that economic growth is increased by the improvement in the financial development. On the contrary, if financial development exceeds the threshold, then there is a negative effect on growth.

Azam and Ahmed (2015) validated growth model through FDI and human capital using data from 10 independent commonwealth countries from 1993 to 2011 by running fixed and random effect. It was concluded that FDI facilitates economic growth while human capital is critical for economic growth. It was recommended that the government give more facilities to MNCs and improve local business conditions.

Nwaogu and Ryan (2015) investigated the impact of FDI, aid and remittances on 53 African and 34 Latin American and Caribbean economies with separate and combined estimations. FDI and Aid affect economic growth in Africa, while only FDI affects growth, when all three variables are used. On the contrary, aid and remittances affect growth in Latin America and the Caribbean, when the variables are used separately.

Zafar, Siddique, Ahmad, and Khan (2016) investigated the effects of remittances, FDI, and Aid on growth in Pakistan during the period of 1985 to 2014. A positive and significant relationship of FDI and remittances was found, while a negative and significant effect of Aid was found on economic growth.

\footnotetext{
${ }^{1} \mathrm{EU}$ consists of developed old countries, transition countries and new EU members' countries
} 
Jibran, Ali, Hayat, and Iqbal (2016) also studied the impact of debt on growth during the years 1972 to 2012 in the long and short run in Pakistan. A negative relationship was proved in the long and short run and the authors suggest that government should rely less on external debts because of their negative effect.

Ibrahim and Dahie (2016) investigated the relationship between FDI, Aid, domestic investment, and Somalia growth by using annual data from 1970 to 2014. A positive and significant effect of FDI, Aid and domestic investment was found on economic growth in Somalia. Similarly, Sjöholm (2016) also found FDI to have a positive effect through value addition in local firms in Indonesia.

The literature discussed above has focused on studying IFI and economic growth mainly through panel and cross-sectional techniques. There is a need to investigate this nexus by using time series analysis with different econometric techniques. The following section covers our model framework for investigating the relationship between IFI and economic growth.

\section{Model and Techniques}

This section discusses the key approach to measure linear relationship between IFI and economic growth with annual time series data from the year 1975 to 2013 . The data were collected from the State Bank of Pakistan and World Bank. The regression model in general forms is as follows:

$$
G D P=f(I F I, I N F, T O P, E L F, R F C, F R, L E P)
$$

In this model, GDP is used as real gross domestic product, whereas IFI, the measure of International Financial Integration index, is used as an independent variable with a set of control variables. These control variables include INF (inflation measured by the GDP-deflator), TOP (Jawaid, 2014) (trade openness measured by trade including both export and import as a percentage of nominal GDP), ELF (employed labor force), RFC (real fixed capital), FR (fertility rate), and LEP (life expectancy used as health variable). The parameter for estimations is developed as follows:

$$
\operatorname{Ln}(Y)=\alpha+\beta \operatorname{Ln}(F)+\operatorname{Ln} \gamma(X)+\mu
$$

Where $\mu$, is used as the error term, Ln is a symbol of the log, $\mathrm{Y}$ is used as a dependent variable, $\mathrm{F}$ is an independent variable used as IFI index, and $\mathrm{X}$ represents a set of control variables.

Augmented Dickey Fuller (ADF), Dickey Fuller-Generalize Least Square (ERS), and KPSS unit root tests were used to examine stationary properties. Autoregressive Distributed Lag (ARDL), Johansen and Juselius (JJ), and Engle and Granger cointegration tests were used to find the long run relationship between IFI and economic growth. ARDL also investigates long-run relationship and single equation cointegartion has advantages over other techniques. Cumulative Sum (CUSUM) and CUSUM of square test was used to check the stability of the model. The Variance Decomposition method analyzed causal 
relationship between IFI and growth. A sensitivity analysis was performed through Fully Modified Ordinary Least Square to check the robustness of the initial result.

\section{Results Analysis}

\section{Stationary}

Generally, financial and economic time series data have a trending behavior like real GDP, FDI, and REM, which needs to be changed into non-trending behavior by running unit root statistic. To achieve this goal, Augmented Dickey-Fuller (ADF) , Dickey-Fuller Generalized Least Square (DF-GLS), and Kwiatkowski, Phillips, Schmidt and Shin (KPSS) tests were used. According to unit root (Table 2), real GDP, financial integration, and all control variables are stationary at I (1), whereas trending behavior is at I (0), which means variables are integrated in one order. After unit root test satisfied a necessary condition to run cointegration techniques, Engle-Granger, Johansen-Juselius and ARDL test statistic were run.

Table 2

Unit Root Statistics

\begin{tabular}{|c|c|c|c|c|c|c|c|c|c|c|c|c|}
\hline \multirow[t]{3}{*}{ Variable } & \multicolumn{4}{|c|}{ ADF test statistics } & \multicolumn{4}{|c|}{ DF-GLS test statistics } & \multicolumn{4}{|c|}{ KPSS test statistics } \\
\hline & \multicolumn{2}{|c|}{ I (0) } & \multicolumn{2}{|c|}{ I (1) } & \multicolumn{2}{|c|}{ I (0) } & \multicolumn{2}{|c|}{ I (1) } & \multicolumn{2}{|c|}{ I (0) } & \multicolumn{2}{|c|}{ I (1) } \\
\hline & $\mathrm{C}$ & $\mathrm{C} \& \mathrm{~T}$ & C & $\mathrm{C} \& \mathrm{~T}$ & $\mathrm{C}$ & $C \& T$ & $\mathrm{C}$ & $C \& T$ & $\mathrm{C}$ & $C \& T$ & $\mathrm{C}$ & $C \& T$ \\
\hline LGDP & -2.293 & -1.288 & -3.939 & -4.587 & 0.429 & -1.38 & -3.983 & -4.563 & 0.755 & 0.228 & 0.344 & 0.102 \\
\hline LIFI & -2.572 & -3.196 & -5.417 & -5.605 & 0.749 & -2.296 & -3.551 & -4.93 & 0.769 & 0.223 & 0.319 & 0.112 \\
\hline LINF & 0.9 & -1.83 & -3.803 & -3.951 & 0.622 & -2.142 & -3.678 & -3.849 & 0.767 & 0.226 & 0.144 & 0.075 \\
\hline LTOP & -2.422 & -2.952 & -6.41 & -6.367 & -1.319 & -2.762 & -3.923 & -5.346 & 0.751 & 0.121 & 0.114 & 0.11 \\
\hline LELF & -0.019 & -1.731 & -6.401 & -6.332 & 1.082 & -1.794 & -6.333 & -6.361 & 0.758 & 0.23 & 0.098 & 0.085 \\
\hline LFR & -1.826 & -2.761 & -3.022 & -3.83 & -1.061 & -2.488 & -2.523 & -3.996 & 1.954 & 0.46 & 0.344 & 0.122 \\
\hline LLEP & -2.206 & 1.854 & -3.234 & -4.447 & 1.053 & -0.06 & 2.355 & -2.94 & 0.759 & 0.239 & 0.414 & 0.098 \\
\hline
\end{tabular}

Source: Author's estimation

Note: The critical values for ADF and DF-GLS (ERS) tests of constant (C) is $-4.219,-3.533,-3.198$ and-2.628, $-1.950,-1.611$ whereas constant \& trend (C \& T) is $-3.621,-2.943,-2.610$ and $-3.770,-3.190,-2.890$, at $1 \%, 5 \%$ \& $10 \%$ level of significance respectively. Contrary, $1 \%, 5 \%, 10 \%$ level is constant (C) $0.739,0.463,0.347$ and (C \& T) $0.216,0.1460,0.119$ in KPSS.

\section{Cointegration}

Table 3 represents the results of Johansen and Juselius (1990); Aman, Sharif, and Arif (2016); Arif and Suleman (2017); Raza, Sharif, Wong, and Karim (2016) multivariate cointegration test with Trace statistic and Maximum Eigenvalue. The null hypothesis of no cointegration is rejected at 5 percent level of significance with eight cointegration equation, and a long run relationship between financial integration and economic growth is proved. 
Table 3

JJ Cointegration

\begin{tabular}{ccccc}
\hline Hypothesis No. of CE(s) & $\begin{array}{c}\text { Trace Statistics } \\
\text { (Calculated Values) }\end{array}$ & $\begin{array}{c}\text { 5\% Critical Values } \\
\text { (Tabulated Values) }\end{array}$ & $\begin{array}{c}\text { Max. Eigen value } \\
\text { (Calculated Values) }\end{array}$ & $\begin{array}{c}\text { 5\% Critical Values } \\
\text { (Tabulated Values) }\end{array}$ \\
\hline None & 530.2437 & 187.4701 & 157.5383 & 56.70519 \\
At Most 1 & 372.7053 & 150.5585 & 86.6063 & 50.59985 \\
At Most 2 & 286.099 & 117.7082 & 73.27214 & 44.4972 \\
At Most 3 & 212.8269 & 88.8038 & 66.65936 & 38.33101 \\
\hline Source: Author's estimation & \multicolumn{3}{c}{}
\end{tabular}

Similarly, Engle and Granger (1987) test (Table 4) confirms a long run relationship by running ADF, DF-GLS, and KPSS at I (0).

Developed by M. H. Pesaran, Shin, and Smith (2001), Autoregressive Distributed Lag (ARDL) is based on a general to specific technique for investigating a long run relationship. Generally, it is run from unrestricted vector autoregressive (VAR) to determine lag length criterion by using Schwarz Bayesian Criterion (SBC) with smallest possible lag length, or Akaike Information Criterion (AIC) with possible maximum lag length.

Table 4

Residual-based Engle and Granger Co-integration

\begin{tabular}{lcc}
\hline Test & Constant & Constant \& Trend \\
\hline ADF & -4.739 & -4.68 \\
DF-GLS & -3.344 & -4.24 \\
KPSS & 0.086 & 0.087 \\
\hline Source: Author's estimation & \\
The critical values for ADF and DF-GLS tests constant $(\mathrm{C})$ is $-3.615,-2.941$, \\
-2.609 and $-2.627,-1.949,-1.6114$ where constant and trend $(\mathrm{C} \& \mathrm{~T})$ is -4.219, \\
$-3.533,-3.198$ and $-3.770,-3.190,-2.890$. Similarly, KPSS constant $(\mathrm{C})$ is \\
$0.739,0.463,0.347$ where constant and trend (C\&T) is $0.216,0.146,0.119$ \\
at $1 \%, 5 \% \& 10 \%$ level of significance respectively.
\end{tabular}

ARDL result in Table 5 confirms cointegration because calculated F-statistics is 11.761 , which is greater than the critical value of upper level bound at 5 percent level of significance. The adjustment of coefficient in error correction (ECT) stands insignificant.

Table 5

Lag Length Selection \& Bound Testing for Cointegration

\begin{tabular}{cccc}
\hline Lags Order & AIC & SBC & F-Test Statistics \\
\hline 0 & -24.383 & -24.031 & \\
1 & -46.803 & -43.635 & $* 11.761$ \\
2 & -51.245 & -45.263 & \\
3 & $-55.785^{*}$ & $-46.988^{*}$ & \\
Source: Authors' estimation. \\
* 5\% level of significant.
\end{tabular}

\section{Ordinary Least Square Regression}

Table 6 shows the long-run relationship between IFI and economic growth. There is a significant negative impact of Financial integration on economic growth in the long run. The study also found a positive significant effect of inflation, trade openness, employed 
labor force, real fixed capital, fertility rate, and life expectancy. Initial regression model applied Newey-West HAC procedure because it corrects the issue of autocorrelation and heteroscedasticity.

\section{Variance Decomposition Method}

A number of past studies have used Granger causality and Toda \& Yamamoto analysis to check causality effects, but it has a limitation (i.e. among the variables beyond selected time period) and cannot capture relative strength of a causal relationship. Due to this problem, Pesaran and Shin (1998) developed the Variance Decomposition Method (VDM). Table $7 \mathrm{a}$ and $7 \mathrm{~b}$ measure the percentage of variation in economic growth due to innovative

\begin{tabular}{cccc}
$\begin{array}{l}\text { Table 6 } \\
\text { Long Run Regression }\end{array}$ & & & \\
\hline Variables & Coefficient & T-Stats & Prob. \\
\hline C & -21.93122 & -7.091079 & 0 \\
LIFI & -0.192111 & -1.979657 & 0.0567 \\
LINF & 0.230565 & 3.722355 & 0.0008 \\
LTOP & 0.132234 & 1.979662 & 0.0567 \\
LELF & 0.367543 & 2.931398 & 0.0063 \\
LRFC & 0.142073 & 4.200729 & 0.0002 \\
LFR & 0.501439 & 4.96619 & 0 \\
LLEP & 7.309236 & 7.763371 & 0 \\
\hline Adj. $R^{2}$ & & 0.998 & \\
F-stats (Prob.) & $3509.363(0.000)$ & \\
Durbin-Watson stat & & 1.375 & \\
\hline Source: Authors' estimation. & &
\end{tabular}

shocks itself, as well as financial integration and control variables. Results indicate $100 \%$ and $16.68 \%$ of the variation in real GDP explained by its own at first and tenth period, and $11.69 \%$ and $31.23 \%$ of the variation in real GDP is explained by IFI at fifth and tenth period, which means variation in real GDP will not be heavily influenced by IFI in future. Results also indicate that $89 \%$ and $61 \%$ of the variation in IFI is explained by its own at first and tenth period, and $12.13 \%$ and $12.82 \%$ of the variation in IFI is explained by real GDP. These results prove a bidirectional causal relationship between GDP and IFI.

Table $7 \mathrm{a}$

Variance Decomposition of LGDP Results

\begin{tabular}{ccccccccc}
\hline \multirow{2}{*}{ Period } & LGDP & LIFI & LINF & LTOP & LELF & LRFC & LFR & LLEP \\
\hline 1 & 100.0000 & 0.000000 & 0.000000 & 0.000000 & 0.000000 & 0.000000 & 0.000000 & 0.000000 \\
2 & 69.21694 & 0.324068 & 9.056824 & 0.236044 & 2.194033 & 15.06180 & 1.951315 & 1.958976 \\
3 & 33.44035 & 0.175491 & 5.297985 & 0.668770 & 2.918383 & 54.07736 & 2.169044 & 1.252622 \\
4 & 25.32750 & 4.256008 & 4.574297 & 1.664234 & 2.922668 & 57.12411 & 3.049516 & 1.081667 \\
5 & 21.49922 & 11.69486 & 3.678430 & 3.793998 & 3.010015 & 51.85229 & 3.618739 & 0.852447 \\
6 & 18.06752 & 18.91110 & 3.497954 & 5.973122 & 2.745545 & 46.19487 & 3.783299 & 0.826602 \\
7 & 16.15657 & 25.25471 & 3.178407 & 7.160293 & 2.528466 & 41.29373 & 3.630732 & 0.797080 \\
8 & 15.80525 & 28.54594 & 2.955053 & 7.440964 & 2.364602 & 38.75971 & 3.351836 & 0.776636 \\
9 & 16.08299 & 30.35706 & 2.779943 & 7.714099 & 2.233880 & 36.90563 & 3.188089 & 0.738310 \\
10 & 16.68093 & 31.23552 & 2.657827 & 8.022392 & 2.134145 & 35.25062 & 3.312567 & 0.705995 \\
\hline
\end{tabular}




\section{Sensitivity Test}

Phillips and Hansen (1990) developed Fully Modified Ordinary Least Square (FMOLS) technique to check robustness as it removes serial correlation and endogeneity issues from regressors. The results of FMOLS (Table 8) prove a long run relation between financial integration and economic growth which initial regression had found.

Table $7 \mathrm{~b}$

Variance Decomposition of LIFI Results

\begin{tabular}{|c|c|c|c|c|c|c|c|c|}
\hline Period & LGDP & LIFI & LINF & LTOP & LELF & LRFC & LFR & LLEP \\
\hline 1 & 10.00015 & 89.99985 & 0.000000 & 0.000000 & 0.000000 & 0.000000 & 0.000000 & 0.000000 \\
\hline 2 & 9.504223 & 85.03733 & 0.018881 & 2.898363 & 0.164744 & 2.166562 & 0.018590 & 0.191302 \\
\hline 3 & 8.475465 & 73.94881 & 0.302330 & 3.895374 & 0.318660 & 12.76609 & 0.016751 & 0.276518 \\
\hline 4 & 11.02651 & 69.11662 & 1.413273 & 3.805710 & 0.299550 & 14.05232 & 0.017105 & 0.268914 \\
\hline 5 & 12.13194 & 68.07313 & 1.384325 & 3.726242 & 0.297733 & 14.04477 & 0.066300 & 0.275554 \\
\hline 6 & 12.42315 & 64.99100 & 1.432649 & 3.592911 & 0.304627 & 16.74141 & 0.171677 & 0.342575 \\
\hline 7 & 13.06238 & 62.30903 & 1.373535 & 3.425732 & 0.297031 & 18.93788 & 0.241141 & 0.353276 \\
\hline 8 & 13.10902 & 61.65813 & 1.329610 & 3.885405 & 0.297965 & 19.10771 & 0.267784 & 0.344376 \\
\hline 9 & 12.92462 & 61.58999 & 1.331287 & 4.565299 & 0.289218 & 18.69856 & 0.262007 & 0.339021 \\
\hline 10 & 12.82951 & 61.72188 & 1.306297 & 4.942020 & 0.288937 & 18.29113 & 0.281276 & 0.338952 \\
\hline
\end{tabular}

Table 8

Results of Fully Modified Ordinary Least Square

\begin{tabular}{cccc}
\hline Variables & Coefficient & T-Stats & Prob. \\
\hline C & -22.59566 & -8.060138 & 0 \\
LIFI & -0.230792 & -3.011386 & 0.0052 \\
LINF & 0.239045 & 4.626748 & 0.0001 \\
LTOP & 0.126388 & 1.96531 & 0.0587 \\
LELF & 0.454301 & 3.878269 & 0.0005 \\
LRFC & 0.150306 & 4.15551 & 0.0002 \\
LFR & 0.573132 & 6.989434 & 0 \\
LLEP & 7.421366 & 8.762336 & 0 \\
\hline Adj. $R^{2}$ & 0.998 \\
D.W stats & 1.483 \\
\hline Source: Authors' Estimation
\end{tabular}

\section{Stability Test}

Monk and Brown (1975) ensure structural stability of an estimated model by using cumulative sum (CUSUM) and the cumulative sum of square (CUSUMQ) techniques. CUSUM test detects instability of coefficient and CUSUMQ test detects random instability of coefficient.

Figures 2 and 3 highlight, with plots of CUSUM and CUSUMQ, that both critical bonds are at 5 percent level of significance. This proves that estimated coefficients are stable over the period by rejecting the null hypothesis. 
Figure 2

Test of Stability
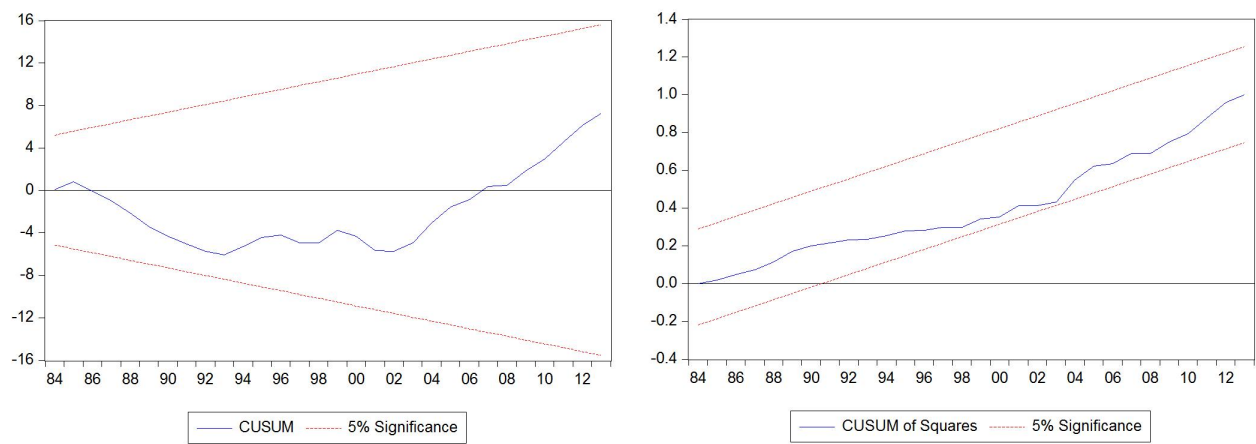

\section{Conclusion and Policy Suggestion}

This study explores the long run relationship between IFI and economic growth in the context of Pakistan by using time series data from 1975 to 2013. IFI, used as an independent variable, comprises foreign direct investment, remittances, and external debts in index. Results acknowledge a negative and significant effect of international financial integration on economic growth of Pakistan, whereas cointegration results confirm a significant long run relationship. Variance decomposition method proves bidirectional causal relationship and sensitivity analysis confirms the robustness of initial result through FMOLS. Cusum and Cusum of square stability test confirms that coefficients are stable over a long time.

It is also indicated that the impact of international capital on growth mainly depends on the government policies and local business conditions. Similarly, countries with better institutions (less corruption, better corporate and public governance) attract relatively more investment and equity flows rather than debts. As discussed earlier, external debts have had a large share in IFI compared to other types of inflow during the last couple of decades, which could be the reason of the negative effect of IFI. Although Pakistan's current foreign capital policy is reasonably attractive, the outcomes do not meet the desired levels, beacuse financial integration in rather extreme scenarios is unlikely to be achieved through policy reform. Therefore, the government should focus on financial and regulatory reforms that may eliminate barriers and promote financial development.

It is suggested that government facilitate domestic traders to stabilize domestic investment, productivity, and trade by developing a domestic financial system and increasing trade openness through minimizing trade constraint and alleviating poverty. The government should rely less on external borrowing because it raises debt share in IFI, instead it should promote remittances and FDI through appropriate measures, such as developing telecommunication facilities, road and rail networks, skilled labour, and a transparent trade policy. A deep and well-supervised financial system is essential for efficiently intermediating foreign finance into productive investments. 


\section{References}

Alam, M. S., Raza, S. A., Shahbaz, M., \& Abbas, Q. (2016). Accounting for contribution of trade openness and foreign direct investment in life expectancy: The long-run and short-run analysis in pakistan. Social Indicators Research, 129(3), 1155-1170.

Alfaro, L., Chanda, A., Kalemli-Ozcan, S., \& Sayek, S. (2004). FDI and economic growth: The role of local financial markets. Journal of International Economics, 64 (1), 89112.

Aman, A., Sharif, S., \& Arif, I. (2016). Comparison of islamic banks with conventional banks: Evidence from an emerging market. Journal of Management Sciences, 3(1), $13-22$.

Arif, I., \& Suleman, T. (2017). Terrorism and stock market linkages: An empirical study from a front-line state. Global Business Review, 18(2), 1-14.

Azam, M., \& Ahmed, A. M. (2015). Role of human capital and foreign direct investment in promoting economic growth: Evidence from Common wealth of independent states. International Journal of Social Economics, 42(2), 98-111.

Baele, L., Ferrando, A., Hördahl, P., Krylova, E., \& Monnet, C. (2004). Measuring European financial integration. Oxford Review of Economic Policy, 20(4), 509-530.

Christopoulos, D. K., \& Tsionas, E. G. (2004). Financial development and economic growth: Evidence from panel unit root and cointegration tests. Journal of Development Economics, $73(1), 55-74$.

De Gregorio, J. (1999). Financial integration, financial development and economic growth. Universidad de Chile. Facultad de Economía y Negocios, 26(2), 137-161.

Edison, H. J., Levine, R., Ricci, L., \& Sløk, T. (2002). International financial integration and economic growth. Journal of International Money and Finance, 21 (6), 749-776.

Engle, R. F., \& Granger, C. W. J. (1987). Co-integration and error correction: Representation, estimation, and testing. Econometrica, 55(2), 251-276.

Epaulard, A., \& Pommeret, A. (2005). Financial integration, growth, and volatility. International Monetary Fund Working Paper No. 67.

Farid, S. (2013). Financial integration in African emerging markets. In African Economic Conference (pp. 1-18).

Filmer, D., \& Pritchett, L. H. (2001). Estimating wealth effects without expenditure data or tears: An application to educational enrollments in states of India. Demography, $38(1), 115-132$.

Guiso, L., Jappelli, T., Padula, M., \& Pagano, M. (2004). Financial market integration and economic growth in the EU. Economic Policy, 19(40), 524-577.

Hotelling, H. (1933). Analysis of a complex of statistical variables into principal components. Journal of Educational Psychology, 24(6), 417.

Hye, Q. M. A., \& Lau, W.-Y. (2015). Trade openness and economic growth: Empirical evidence from India. Journal of Business Economics and Management, 16(1), 188205.

Ibrahim, A. A., \& Dahie, A. M. (2016). The effect of foreign direct investment, foreign aid and domestic investment on economic growth: Evidence from Somalia. Imperial Journal of Interdisciplinary Research, 2(12), 633-640. 
Jawaid, S. T. (2014). Trade openness and economic growth: A lesson from Pakistan. Foreign Trade Review, 49(2), 193-212.

Jibran, K., Ali, A., Hayat, U., \& Iqbal, A. (2016). Public debt and economic growth in Pakistan: A reassessment. Pakistan Business Review, 18(2), 307-324.

Johansen, S., \& Juselius, K. (1990). Maximum likelihood estimation and inference on cointegration with applications to the demand for money. Oxford Bulletin of Economics and Statistics, 52(2), 169-210.

Khan, M. A. (2007). Financial sector restructuring in Pakistan. MPRA Paper No.4141.

Khan, M. A., Qayyum, A., Sheikh, S. A., \& Siddique, O. (2005). Financial Development and Economic Growth: The Case of Pakistan. The Pakistan Development Review, $44(4), 819-837$.

Kolenikov, S., \& Angeles, G. (2009). Socioeconomic status measurement with discrete proxy variables: Is principal component analysis a reliable answer? Review of Income and Wealth, 55(1), 128-165.

Kose, M. A., Prasad, E. S., \& Taylor, A. D. (2011). Thresholds in the process of international financial integration. Journal of International Money and Finance, 30(1), 147-179.

Kose, M. A., Prasad, E. S., \& Terrones, M. E. (2003). Financial integration and macroeconomic volatility. IMF Economic Review, 50(1), 119-142.

Kose, M. A., Prasad, E. S., \& Terrones, M. E. (2006). How do trade and financial integration affect the relationship between growth and volatility? Journal of International Economics, 69(1), 176-202.

Law, S. H., \& Singh, N. (2014). Does too much finance harm economic growth? Journal of Banking \& Finance, 41(1), 36-44.

Levine, R. (2001). International financial liberalization and economic growth. Review of International Economics, 9(4), 688-702.

Markusen, J. R., \& Venables, A. J. (1999). Foreign direct investment as a catalyst for industrial development. European Economic Review, 43(2), 335-356.

Masten, A. B., Coricelli, F., \& Masten, I. (2008). Non-linear growth effects of financial development: Does financial integration matter? Journal of International Money and Finance, 27(2), 295-313.

Monk, T. H., \& Brown, B. (1975). The effect of target surround density on visual search performance. Human Factors: The Journal of the Human Factors and Ergonomics Society, $17(4), 356-360$.

Mougani, G. (2012). An analysis of the impact of financial integration on economic activity and macroeconomic volatility in Africa within the financial globalization context. African Development Bank, Tunisia Working Paper No. 144.

Nwaogu, U. G., \& Ryan, M. J. (2015). FDI, foreign aid, remittance and economic growth in developing countries. Review of Development Economics, 19(1), 100-115.

Pearson, K. (1901). Principal components analysis. The London, Edinburgh and Dublin Philosophical Magazine and Journal, 6(2), 559-572.

Pesaran, \& Shin, Y. (1998). Generalized impulse response analysis in linear multivariate models. Economics Letters, 58(1), 17-29. 
Pesaran, M. H., Shin, Y., \& Smith, R. J. (2001). Bounds testing approaches to the analysis of level relationships. Journal of Applied Econometrics, 16 (3), 289-326.

Phillips, P. C., \& Hansen, B. E. (1990). Statistical inference in instrumental variables regression with I (1) processes. The Review of Economic Studies, 57(1), 99-125.

Prasad, E., Rogoff, K., Wei, S.-J., \& Kose, M. A. (2003). Effects of financial globalization on developing countries: Some empirical evidence. International Monetary Fund, Occasional Paper No. 220.

Raza, S. A., \& Karim, M. Z. A. (2016). Do liquidity and financial leverage constrain the impact of firm size and dividend payouts on share price in emerging economy. Journal of Finance and Economics Research, 1(2), 73-88.

Raza, S. A., Sharif, A., Wong, W. K., \& Karim, M. Z. A. (2016). Tourism development and environmental degradation in the United States: Evidence from wavelet-based analysis. Current Issues in Tourism, 1-23. doi: 10.1080/13683500.2016.1192587

Schularick, M., \& Steger, T. M. (2006). Does financial integration spur economic growth? New evidence from the first era of financial globalization. CESIFO Working paper No. 1691.

Sharif, A., \& Raza, S. A. (2016). Dynamic relationship between urbanization, energy consumption and environmental degradation in Pakistan: Evidence from structure break testing. Journal of Management Sciences, 3(1), 01-21.

Sjöholm, F. (2016). Foreign direct investment and value added in Indonesia. School of Economics and Management, Working Paper No. 31.

Tayebi, S. K., \& Fakhr, Z. S. (2009). Determinants of financial integration in the East Asia-Pacific region. Iranian Economic Review, 14(23), 155-173.

Zafar, S. Z., Siddique, M., Ahmad, H., \& Khan, T. A. (2016). The economic implications of remittances on economic growth: The case study of Pakistan. International Journal of Academic Research in Business and Social Sciences, 6(7), 215-222. 